\title{
Does Happiness Promote Career Success?
}

\author{
Julia K. Boehm \\ Sonja Lyubomirsky \\ University of California, Riverside
}

Past research has demonstrated a relationship between happiness and workplace success. For example, compared with their less happy peers, happy people earn more money, display superior performance, and perform more helpful acts. Researchers have often assumed that an employee is happy and satisfied because he or she is successful. In this article, the authors review evidence in support of an alternative hypothesis - namely, that happiness is a source of why particular employees are more successful than others. To this end, the authors consider evidence from three types of studies - cross-sectional, longitudinal, and experimental - that relate happiness to various work outcomes. Taken together, the evidence suggests that happiness is not only correlated with workplace success but that happiness often precedes measures of success and that induction of positive affect leads to improved workplace outcomes.

Keywords: happiness; subjective well-being; positive emotion; work; career; success

A wealth of research suggests that happy and satisfied individuals are relatively more successful in the workplace. For example, happiness is related to income (Diener \& Biswas-Diener, 2002), favorable evaluations by a superior (Cropanzano \& Wright, 1999), helping fellow workers (George, 1991), and social support from colleagues and supervisors (Iverson, Olekalns, \& Erwin, 1998). Most researchers have assumed that the accomplishment of such indicators of success in the workplace causes a person to be happy. In fact, the alternative hypothesis - that happiness causes success - may be equally plausible. In this article, we review the available literature to support the idea that happiness is an important precursor and determinant of career success.

We define a happy person as someone who frequently experiences positive emotions. Examples of positive emotions include joy, satisfaction, contentment, enthusiasm, and interest. The experience of slightly to moderately intense positive emotions most of the time has been found to be a strong predictor of judgments of happiness (Diener, Sandvik, \& Pavot, 1991). Indeed, intense positive emotions do not predict happiness as well as low-grade but frequent positive emotions. 
Throughout this article, we use the terms happy, high positive affect, greater positive emotions, and higher well-being interchangeably to describe a person who feels mostly positive emotions (relative to negative emotions) most of the time.

Our focus on positive emotions is not arbitrary. We argue that happiness leads to success precisely through the experience of positive affect. Although the exact mechanism is still unclear, several pathways are likely. First, prior research suggests that positive emotions are associated with approach-oriented behavior (Elliot \& Thrash, 2002; Watson, Wiese, Vaidya, \& Tellegen, 1999). That is, people in a good mood are more likely to enter novel situations, interact with other people, and pursue new goals (Carver, 2003). Positive emotions also signal that life is good and that no threats are readily apparent (Cantor et al., 1991; Carver \& Scheier, 1998). According to Fredrickson (1998, 2001), a safe and comfortable environment allows one to "broaden and build" intellectual, social, and physical resources, which can be called on in later times of need. Armed with previously acquired resources and primed to pursue new goals, people who experience positive affect are particularly well suited to experience success. In the literature review that follows, we seek to demonstrate that happy people enjoy more success in the workplace than their less happy peers and that such success is triggered by the experience of positive emotions.

To this end, we consider three types of investigations to build our case-crosssectional, longitudinal, and experimental. Cross-sectional studies provide correlational evidence of a relationship between happiness and career outcomes. Although cross-sectional evidence cannot establish a causal relationship between variables, it is nonetheless critical to include, as it verifies that a relationship between two variables exists. By contrast, longitudinal studies speak to the question of causal direction by providing evidence of temporal order. In other words, if happiness is observed prior to career success, then the reverse causal pathfrom success to happiness - cannot be supported. One limitation of both longitudinal and cross-sectional evidence, however, is that the possibility always exists that a third variable (like conscientiousness, sociability, or intelligence) could simultaneously determine both career success and happiness. Fortunately, experimental studies that induce positive (or negative) emotions via random assignment provide the strongest evidence for causality. Unfortunately, such laboratory experiments can only manipulate relatively low and transient levels of affect and, moreover, often lack external validity, which makes it difficult to pinpoint the exact causal mechanism. However, although cross-sectional, longitudinal, or experimental investigations alone cannot provide sufficient support for our thesis, all three taken together offer a persuasive body of evidence supporting the notion that happiness plays a role in workplace success.

In this article, we ask three primary questions that are uniquely relevant to each type of evidence considered. Cross-sectional evidence, the most abundant evidence available, can address the question of whether happy people are relatively more likely to engage in adaptive workplace behaviors (or behaviors paralleling success) and to be more accomplished in their careers. Longitudinal evidence can establish 
whether happiness precedes success in the workplace. And finally, experimental evidence can determine whether laboratory-induced happiness produces superior workplace outcomes. What follows is a review of the literature relevant to each of the above questions.

\section{CROSS-SECTIONAL EVIDENCE: DO HAPPY PEOPLE ENGAGE IN SUCCESSFUL BEHAVIORS AND ARE MORE ACCOMPLISHED IN THE WORKPLACE?}

In general, people who experience a preponderance of positive emotions enjoy more beneficial outcomes in the workplace than those who experience lower levels of positive emotions. To begin, employees with high positive affect have jobs that involve a wide range of tasks and are described as more meaningful and more autonomous (Staw, Sutton, \& Pelled, 1994). Other studies also support the idea that happy people have a higher degree of autonomy in their jobs than their less happy peers and that such increased control of the environment may buffer against burnout (Iverson et al., 1998; see also Van Katwyk, Fox, Spector, \& Kelloway, 2000). Such job qualities may be associated with enhanced workplace success because they make a job more pleasant.

Besides describing their job more positively, happy people are also more satisfied with their jobs compared with unhappy people (Connolly \& Viswesvaran, 2000; George, 1995; Fisher, 2002; Judge \& Ilies, 2004; Judge, Thoresen, Pucik, \& Welbourne, 1999; Mignonac \& Herrbach, 2004; Thoresen, Kaplan, Barsky, Warren, \& de Chermont, 2003; Weiss, Nicholas, \& Daus, 1999). Although many attempts have been made to demonstrate a connection between job satisfaction and job performance (Iaffaldano \& Muchinsky, 1985), the findings have been inconsistent (Judge, Thoresen, Bono, \& Patton, 2001). In response to the mixed evidence, some researchers have reconsidered the primarily cognitive conceptualization of job satisfaction and have instead begun to focus on its affective component. Indeed, it appears that positive affect is a good predictor of job performance (Wright \& Cropanzano, 2000), and this link is evident across diverse work environments. For example, supervisors review happy people relatively more favorably (Cropanzano \& Wright, 1999; Judge et al., 1999; Staw et al., 1994; Wright \& Staw, 1999), sales managers with high positive affect oversee salespeople who are rated as high performing (George, 1995), and happy cricket players show superior performance during games (Totterdell, 1999, 2000). In one study, the happiness of dormitory resident assistants predicted how effective they were judged by residents (DeLuga \& Mason, 2000).

In addition to being judged by others as strong performers, happy employees perform relatively better on more "objective" work-related tasks. For example, in one study, business students with high positive affect were better decision makers and had superior interpersonal skills - both important characteristics of successful managers - than those with lower positive affect (Staw \& Barsade, 1993). 
Indeed, judges rated the happy students as having greater managerial potential than the others. Furthermore, insurance agents with a positive disposition have been found to sell more insurance policies than their less positive counterparts (Seligman \& Schulman, 1986). Although such correlational evidence does not prove causality, some preliminary data suggest that the relationship between happiness and performance can be bidirectional. In other words, happy moods lead workers to perform better and better performance produces happy moods; the two components mutually reinforce each other (Coté, 1999).

Superior performance by happy employees is not limited to tasks explicitly prescribed by the job position. The presence of positive affect predicts behavior that extends beyond a job description but that benefits other individuals or the organization itself (Borman, Penner, Allen, \& Motowidlo, 2001; Credé, Chernyshenko, Stark, Dalal, \& Bashshur, 2005; Fisher, 2002; George, 1991; Ilies, Scott, \& Judge, 2006; Lee \& Allen, 2002; Miles, Borman, Spector, \& Fox, 2002; Williams \& Shiaw, 1999). Such behavior has been called, among other things, "organizational citizenship behavior" and entails acts involving altruism, courtesy, and conscientiousness. Similar taxonomies include behaviors like exerting extra effort, volunteering for optional tasks, helping others, and being cooperative (Borman et al., 2001), as well as protecting the organization, offering suggestions for improvements, developing personal skills, and spreading goodwill (George \& Brief, 1992). All of these behaviors are related, in that they both enhance an organization's functioning and correlate with positive emotions. Indeed, happy people are more likely to help fellow workers and customers than unhappy people (George, 1991). Even the number of hours a person volunteers for organizations outside the workplace is related to higher well-being (Thoits \& Hewitt, 2001). As most job descriptions do not specify every task that an employee could do to support an organization, employees with positive emotions thus are essentially going "above and beyond" to enhance the functioning of an organization.

Furthermore, workers who experience positive emotions not only go beyond their required duties at work, but they are more invested and involved in their jobs (George, 1995). Indeed, the opposite of job involvement-that is, withdrawal behavior such as burnout, absenteeism, and turnover-are all negatively related to high positive affect (Credé et al., 2005; Miles et al., 2002; Thoresen et al., 2003). In other words, happy people show less burnout (Iverson et al., 1998), less emotional exhaustion (Wright \& Cropanzano, 1998), and less absenteeism (George, 1989; Gil et al., 2004), and they are less likely to quit their jobs (Van Katwyk et al., 2000) than unhappy people. Employees with high positive affect are also better able to cope with organizational change than employees with low positive affect (Judge et al., 1999). In sum, workers with high positive affect are more committed to their organization (Herrbach, 2006; Judge et al., 1999; Mignonac \& Herrbach, 2004; Thoresen et al., 2003) and do not typically engage in withdrawal behavior as a response to dissatisfaction in the workplace. These findings have important implications, as withdrawal behavior can be costly for an organization in terms of productivity loss and retraining expenses. 
A happy person's involvement and commitment to the workplace does not go unnoticed by others. Indeed, managers with a positive mood at work receive more rewards from their supervisors (George, 1995). Furthermore, a small relationship between well-being and income exists, such that as well-being increases, so does income (Judge et al., 1999; Pinquart \& Sorensen, 2000). (In fact, wellbeing and income are more strongly associated than education and income.) At higher levels of income, however, additional factors such as desires, expectations, and social comparisons appear to moderate the relationship between income and well-being (Diener \& Biswas-Diener, 2002). Thus, happiness is more relevant to income at the low end of the pay scale.

Besides the material advantages that happy employees reap, they accrue additional benefits in the form of interpersonal rewards. For example, people who experience more positive emotions receive more social support from both colleagues and supervisors (Iverson et al., 1998). One explanation for this finding is that it is pleasant to help others who are generally positive and cheerful. Or coworkers may offer support because happy workers tend to be cooperative (Miles et al., 2002). For example, happy chief executives with managerial teams also high in positive affect experience relatively less conflict and more cooperation (Barsade, Ward, Turner, \& Sonnenfeld, 2000). Furthermore, those same managerial teams feel relatively more satisfied about group relations.

In general, people with a positive disposition are more likely to be favorably evaluated by their friends compared to people without such a disposition (Taylor, Lerner, Sherman, Sage, \& McDowell, 2003). In an oft-cited study, women who expressed more sincere positive emotions in their yearbook photos were judged as more sociable, pleasant, and warm compared with women who expressed less sincere positive emotion (Harker \& Keltner, 2001). Furthermore, when the yearbook judges were asked to imagine interacting with the women in the photos, they responded differently depending on whether genuine positive emotions were expressed. The judges showed greater interest and more positive expectations of the interaction toward women who expressed genuine positive emotions. In sum, happy people tend to be more popular and likable than unhappy people (Bell, 1978; Feingold, 1983), which suggests that interpersonal exchanges may be more rewarding for those with high positive affect.

Based on the correlational data presented here, happiness is indeed associated with evidence of success in the workplace. Happy employees have more engaging and autonomous jobs, they are more satisfied with their jobs, and they show superior performance in the workplace than less happy employees. Furthermore, happy workers are more likely to engage in beneficial extrarole behaviors and less likely to engage in withdrawal behaviors. Finally, employees with high positive affect garner both material and interpersonal rewards. Although such crosssectional evidence only allows for correlational inferences, we now turn to longitudinal evidence, which supplements the cross-sectional data by establishing a temporal order for the incidence of happiness and success. 


\section{LONGITUDINAL EVIDENCE: DOES HAPPINESS PRECEDE SUCCESS IN THE WORKPLACE?}

Longitudinal evidence provides further support to the argument that happiness promotes workplace success. If researchers measure happiness prior to observing workplace outcomes, they can be more confident in the direction of causality. When the longitudinal studies-although few in number-are considered in conjunction with the cross-sectional studies, a more convincing picture emerges. This evidence is considered below.

Even before a happy person obtains a job, he or she is more likely to receive a second interview than a less happy peer (Burger \& Caldwell, 2000). In a study that tracked graduating students in their job searches, researchers measured positive affect prior to college graduation. Approximately 3 months later, students indicated how well their job search had proceeded. Students who had reported high positive affect were more likely to have been invited to follow-up interviews than those with low positive affect. This suggests that positive emotions can provide people with a distinct advantage when searching for a job.

Successful work outcomes extend beyond initial interviews, however. In an 8year study following adolescents, positive affect measured at age 18 predicted certain work outcomes at age 26 (Roberts, Caspi, \& Moffitt, 2003). For example, happiness was related to subsequent attainment in the workplace, to later job satisfaction (see also Watson \& Slack, 1993), and to subsequent financial security. It is interesting that positive job characteristics can also enhance positive affect concurrently, which suggests that a bidirectional relationship of mutually reinforcing variables may exist. That is, happiness can foster particular job characteristics, which, in turn, enhance one's happiness and activate an upward spiral over time.

Further longitudinal evidence supports that a specific kind of job characteristicnamely, social support-is affected by positive affect. Employees who reported positive emotions during the first measurement period received greater support from both colleagues and supervisors when followed up more than a year later (Staw et al., 1994). Furthermore, supervisors rated those same employees more favorably. Other researchers have replicated the finding that happy employees, when compared with their less happy colleagues, receive more positive evaluations from their superiors up to several years after positive emotions were measured (e.g., Cropanzano \& Wright, 1999; Wright \& Staw, 1999).

Favorable supervisor ratings are imperfect, however, because they may be partially explained by a "halo" effect, such that happy people are bestowed with desirable characteristics because they already have a desirable trait. Fortunately, objective measures provide further evidence that happy people are better performers. For example, life insurance sales agents were investigated during their first year on the job (Seligman \& Schulman, 1986). Those with a strong positive disposition sold more insurance policies during the second half of the year than those without such a disposition. Furthermore, those with a positive outlook were more likely to 
remain at their job 1 year later. Given the notoriously low employee retention rate in the life insurance industry, it is particularly noteworthy that a positive thinking style-also common to happiness - could predict retention.

Additional longitudinal evidence supports the notion that happy employees are more likely to remain at their jobs (Pelled \& Xin, 1999). To illustrate, researchers assessed the positive affect of a variety of employees at an electronics company (including supervisors, administrative staff, and engineers) and then tracked their absence rate in the months that followed. Results indicated that positive emotions and absence were negatively related, such that those employees who were the happiest were the least likely to be absent from work.

Happy people are also less likely to lose their jobs and to be unemployed than less happy people (Diener, Nickerson, Lucas, \& Sandvik, 2002; Marks \& Fleming, 1999). Furthermore, if a happy person does happen to be unemployed, he or she is likely to find a new job more quickly than an unhappy unemployed person (Marks \& Fleming, 1999). Notably, in a 15-year study that followed 24,000 German citizens, those people who had lost their jobs reported low life satisfaction prior to their unemployment (Lucas, Clark, Georgellis, \& Diener, 2004). Thus, positive affect and related constructs seem to offer one measure of protection against a particularly strong and negative indicator of career successnamely, unemployment.

Finally, the relationship between positive emotions and income, a classic marker of workplace success, is supported by longitudinal evidence. That is, people who describe themselves as happy at one point in their lives earn more at later points (Diener et al., 2002; Graham, Eggers, \& Sukhtankar, 2004; Marks \& Fleming, 1999; Staw et al., 1994). For example, in an Australian panel study examining several different adult cohorts, increases in participants' well-being were related to increases in money earned (Marks \& Fleming, 1999). In another study, 13,000 first-year college students rated their cheerfulness in comparison with an average peer (Diener et al., 2002). Sixteen years later, the same participants indicated their income. Cheerful students-particularly those with highincome parents - tended to earn more money in their 30s than their less cheerful counterparts. These findings suggest that happy people are more likely to acquire greater wealth across their lifetimes.

In sum, although the longitudinal evidence seems sparse relative to the abundance of cross-sectional research, the longitudinal studies presented here support our hypothesis that happiness often precedes success. Indeed, this area is ripe for future researchers to track individuals' happiness and career outcomes over time and thus take advantage of the benefits of a longitudinal perspective. The remaining piece of evidence that can clarify the relationship between happiness and career success is experimental. Through the induction of positive emotions via random assignment, researchers can be fairly (although not definitively) certain of cause and effect. The next section reviews experimental evidence related to happiness and workplace success. 


\section{EXPERIMENTAL EVIDENCE: DOES HAPPINESS LEAD TO SUCCESS IN THE WORKPLACE?}

The primary question that experimental evidence can address is whether happiness, or the experience of positive emotions, brings about successful behaviors or outcomes for employees. By inducing positive affect in one group of people and comparing them with a neutral or negative affect group, researchers can draw conclusions about the role of affect in a variety of outcomes. The relevant literature is summarized below.

To start, positive emotions affect group negotiations. In most work environments, employees must interact with other people who may have competing goals and needs. For example, a salesperson may have to bargain with a customer, and a hiring committee must select the best candidate. In such cases, workplace success may involve the capacity of positive emotions to facilitate productive negotiations. In a study involving dyadic discussions about the price of various consumer products, Carnevale and Isen (1986) found that positive moods (induced by reading humorous comics and receiving a gift) were related to beneficial outcomes for both members of the negotiation task. In particular, participants in a positive mood during the discussion showed less contentious behavior, were more cooperative, and were better able to find mutually beneficial solutions than participants who were not in a positive mood.

Other negotiation researchers have substantiated these findings. For example, people with high positive affect have been found to be relatively more likely to manage negotiations through collaboration and cooperation rather than through avoidance or competition (Baron, Fortin, Frei, Hauver, \& Shack, 1990; Barsade, 2002; Forgas, 1998) and to be willing to make more concessions during negotiation (Baron, 1990; Baron, Rea, \& Daniels, 1992). Happy negotiators have also been shown to be initially more optimistic about the outcome of negotiations than their less happy peers (Forgas, 1998). Such a positive outlook may persist throughout the actual negotiations and may be associated with the constructive tactics (e.g., cooperation and collaboration) that happy people choose to employ.

Greater optimism is evident when happy people are working on a solitary task as well. For example, when compared with a neutral affect group, people induced to experience positive affect set higher goals for themselves (Baron, 1990; Hom \& Arbuckle, 1988), persist at a difficult task longer (Sarason, Potter, $\&$ Sarason, 1986), evaluate themselves more positively (Sarason et al., 1986), and rate their performance as stronger (Barsade, 2002; Wright \& Mischel, 1982). On laboratory tasks, people experiencing positive emotions are also more optimistic about the outcomes (Brown, 1984; Wright \& Mischel, 1982). It is interesting that such positive evaluations are not merely unjustified impressions; people in a happy mood often perform better than those in a sad mood (Hom \& Arbuckle, 1988; see below for contradictory findings regarding performance on complex mental tasks). In one study, for example, participants experiencing positive affect 
completed a coding task with greater efficiency than those experiencing neutral affect (Baron, 1990). The high expectations that happy employees set for themselves can produce self-fulfilling prophecies. Thus, happy people's optimistic and self-efficacious thoughts, along with the superior performance that they demonstrate, are instrumental in career advancement and, ultimately, in career success.

In addition to being more optimistic about their own abilities, happy people rate other people more favorably (Baron, 1987, 1993; Baron et al., 1992; Griffitt, 1970). For example, in one study, researchers asked participants to interview and judge a job applicant who happened to be a confederate (Baron, 1993). When the quality of the applicant was ambiguous (versus unmistakably highly or poorly qualified), participants in a happy mood rated him or her as a stronger candidate than those in an unhappy mood. This suggests that a positive mood can transfer to one's impressions of others and thus strengthen relationships, which may engender career success through greater social support.

Experiencing happiness also triggers helpful behavior toward others (Baron et al., 1992). In an experimental context, induced positive moods have been shown to bring about helping in a variety of forms, including making a charitable contribution (Cunningham, Steinberg, \& Grev, 1980; Isen, 1970), sharing with others (Rosenhan, Underwood, \& Moore, 1974), donating blood (O’Malley \& Andrews, 1983), or volunteering one's time (Aderman, 1972; Baron \& Bronfen, 1994; Baron et al., 1992; Berkowitz, 1987; Isen \& Levin, 1972; Rosenhan, Salovey, \& Hargis, 1981). Such evidence bodes well for happy employees and corroborates the crosssectional evidence that they are more likely to help others in a work context.

In jobs where creativity is an asset, the evidence also suggests that positive affect can enhance originality and flexibility (Estrada, Isen, \& Young, 1994; Grawitch, Munz, Elliott, \& Mathis, 2003; Grawitch, Munz, \& Kramer, 2003; Isen, Daubman, \& Nowicki, 1987; Isen, Johnson, Mertz, \& Robinson, 1985; for nonexperimental work, see Madjar, Oldham, \& Pratt, 2002). For example, physicians in a positive mood were able to solve problems more creatively than their neutral mood counterparts (Estrada et al., 1994). Indeed, Isen (1993) reviewed a substantial amount of evidence suggesting that positive affect (rather than arousal) facilitates creativity in various laboratory tasks.

Another relevant finding is that the experience of positive emotions is associated with curiosity (see Kashdan, Rose, \& Fincham, 2004, for nonexperimental evidence) and has been found to "broaden" a person's attention and interests. In an experiment comparing people with induced positive versus neutral affect, those in a good mood expressed a greater desire to be outdoors, to engage in energetic activities, and to be social (Fredrickson \& Branigan, 2005). Thus, experimental data provide additional support to Fredrickson's (1998, 2001) argument that positive affect promotes exploration, playfulness, and creativity.

The evidence suggesting that positive emotions are beneficial while performing complex mental tasks is not as straightforward as that in other areas. For example, positive emotions have been found to hinder logical reasoning (Melton, 1995) and to make it difficult to detect strong versus weak arguments (Mackie \& Worth, 1989). 
Furthermore, people in a negative mood are relatively less likely to use categorical processing (Edwards \& Weary, 1993) and relatively more likely to pay attention to precise procedural steps (Elsbach \& Barr, 1999) and to detect persuasive arguments (Bless, Bohner, Schwarz, \& Strack, 1990). By contrast, other evidence suggests that people with positive emotions disregard irrelevant information and are more efficient at decision-making tasks (Isen \& Means, 1983).

How can such conflicting evidence be reconciled? Recall that positive emotions indicate that life is going well, which allows the individual to direct energy to novel goals. When faced with making an oftentimes artificial mental judgment in the laboratory, happy people may rely on heuristics and preexisting cognitive structures so as to direct more attention to something that they find more relevant or important (Isen \& Means, 1983). Indeed, when happy participants are made aware that additional care is necessary on a given task, they can perform equally as well as unhappy participants (Bless et al., 1990; Bodenhausen, Kramer, \& Süsser, 1994). Thus, it appears that depending on the situation, positive emotions can either facilitate or hamper mental judgments.

In sum, it appears that people experiencing positive emotions use more cooperative strategies when negotiating, have more favorable perceptions of themselves and others, are more self-efficacious, and are more willing and able to help. They also tend to think more creatively and flexibly as well as to engage in and explore their environment to a greater degree. Although the evidence is somewhat mixed regarding the role of positive emotions in mental judgments, it appears that positive affect can facilitate mental functioning in certain contexts.

\section{CONCLUSION}

Taken together, evidence from cross-sectional, longitudinal, and experimental studies supports the hypothesis that positive affect can bring about successful outcomes in the workplace. Happy people are more satisfied with their jobs and report having greater autonomy in their duties. They perform better on assigned tasks than their less happy peers and are more likely to take on extrarole tasks such as helping others. They receive more social support from their coworkers and tend to use more cooperative approaches when interacting with others. Happy people are less likely to exhibit withdrawal behaviors, such as absenteeism, and are less likely to be unemployed. And more generally, happy people are physically healthier, live longer, and cope more effectively with challenges (Lyubomirsky, King, \& Diener, 2005) - characteristics that undoubtedly make it easier to accomplish more in their careers. Accordingly, overall, happy people enjoy greater workplace success, and engage in more behaviors paralleling success, than do less happy people.

We collected evidence in support of these conclusions from three distinct types of investigations. A profusion of cross-sectional studies provided support for 
a link between happiness and workplace success. However, such evidence is unable to prove a causal connection. For example, researchers cannot disentangle whether happiness leads people to acquire jobs with greater autonomy or whether increased autonomy makes people happy. Although less numerous than the cross-sectional studies, the evidence based on the longitudinal data established that happiness and positive affect are often observed prior to workplace success. Such research can rule out the hypothesis that workplace success (assessed at Time 2) fosters happiness (assessed at Time 1). However, further studies are needed to establish that happiness or positive affect at one point in time predicts workplace success at a subsequent point in time, after controlling for earlier levels of resources and success.

Finally, the experimental studies offer a degree of causal support for our hypothesis that positive affect brings about various job-related benefits. It's worth noting, however, that experiments involve inductions of temporary positive mood that occur in relatively less naturalistic contexts and serve only as a proxy for dispositional happiness and naturally occurring positive emotions. However, this may be less of a concern given that we define happiness as the experience of positive emotions most of the time. The possibility also arises that unobserved third variables may be the operative mechanism underlying the happiness-success link. For example, it is critical to determine that positive emotions, rather than the absence of negative emotions, are related to favorable outcomes. Experimental studies that manipulate positive, neutral, and negative affect simultaneously directly address this issue.

Our review also highlighted a number of weaknesses in the available literature for each class of evidence. For example, the longitudinal research consisted mostly of single studies that have not been replicated. This limitation is undoubtedly due to the difficulty and expense involved with tracking participants for extended periods of time. Similarly, the experimental studies featured less variety and breadth than the other classes of evidence. Again, this limitation likely owes to the difficulty or even impossibility of investigating certain outcomes in a laboratory context. For example, it would not be feasible to induce experimental participants into pleasant or unpleasant moods and then track their subsequent income. Despite these individual weaknesses, however, the three classes of evidence collectively offer strong, triangulating support for our hypothesis and help balance the weaknesses of the different types of studies.

Unfortunately, one shortcoming is shared by all three types of evidence - their relative lack of generalizability. Nearly every study presented here included participants from a Western, English-speaking nation (for an exception, see Williams \& Shiaw, 1999). As success in the workplace may be defined differently or may be more or less important in different cultures, the impact of happiness on workplace success may also vary cross-culturally. Future research using participants from a wider range of cultures is needed before these results could be considered representative of a wide cross-section of people. 
Despite the clear successes that happy employees seem to enjoy over less happy employees, it is important to recognize that happiness is not the only resource that can bring success. Other resources such as intelligence, affluence, connections, and perseverance undoubtedly also play a role in career success. Indeed, the particular resource that is most critical to career success - whether it is happiness, street smarts, physical attractiveness, or wealth-is likely to be a function of the career one chooses to pursue.

Similarly, this review is not meant to suggest that unhappy individuals cannot enjoy enormous career success. There are numerous people who are unhappy or dysphoric but happen to be leaders in their fields. Indeed, such prominent figures as Abraham Lincoln and Winston Churchill were reputedly clinically depressed. Presently, our understanding of how negative emotions may engender workplace success is less than clear, but the possibility exists that there are some situations in which unhappy employees show enhanced functioning relative to happy employees. For example, in occupations such as accounting, where attention to detail and precise execution of procedures is necessary, a creative, integrative person who experiences mostly positive affect may not be the ideal job candidate (Lyubomirsky et al., 2005; see Lucas \& Diener, 2003, for additional examples of jobs for which happiness may be detrimental). Identifying areas in which negative emotions may lead to success - for example, in specific job roles or job responsibilities - is an additional area in which future research is needed.

In sum, happiness is not functional in every circumstance that an individual encounters. For example, positive affect would not serve a bank employee well during a robbery. Instead, negative emotions like fear might increase vigilance and prepare the body for action in a threatening situation. Even in routine day-to-day life, people may do well to experience a healthy balance of both positive and negative emotions (Oishi, Diener, \& Lucas, 2006). Thus, our conclusion is not that negative emotions should be ignored but rather that researchers would do well to consider the value of positive emotions in career success. Each type of emotion seems to serve its own purpose, and as this review suggests, positive emotions are particularly well situated to encourage optimal functioning in the workplace.

\section{REFERENCES}

Aderman, D. (1972). Elation, depression, and helping behavior. Journal of Personality and Social Psychology, 24, 91-101.

Baron, R. A. (1987). Interviewer's moods and reactions to job applicants: The influence of affective states on applied social judgments. Journal of Applied Social Psychology, 20, 368-384.

Baron, R. A. (1990). Environmentally induced positive affect: Its impact on self-efficacy, task performance, negotiation, and conflict. Journal of Applied Social Psychology, 20, 368-384.

Baron, R. A. (1993). Interviewers' moods and evaluations of job applicants: The role of applicant qualifications. Journal of Applied Social Psychology, 23, 253-271.

Baron, R. A., \& Bronfen, M. I. (1994). A whiff of reality: Empirical evidence concerning the effects of pleasant fragrances on work-related behavior. Journal of Applied Social Psychology, 24, 1179-1203. 
Baron, R. A., Fortin, S. P., Frei, R. L., Hauver, L. A., \& Shack, M. L. (1990). Reducing organizational conflict: The role of socially-induced positive affect. The International Journal of Conflict Management, 1, 133-152.

Baron, R. A., Rea, M. S., \& Daniels, S. G. (1992). Effects of indoor lighting (illuminance and spectral distribution) on the performance of cognitive tasks and interpersonal behaviors: The potential mediating role of positive affect. Motivation and Emotion, 16, 1-33.

Barsade, S. G. (2002). The ripple effect: Emotional contagion and its influence on group behavior. Administrative Science Quarterly, 47, 644-675.

Barsade, S. G., Ward, A. J., Turner, J. D. F., \& Sonnenfeld, J. A. (2000). To your heart's content: A model of affective diversity in top management teams. Administrative Science Quarterly, 45, 802-836.

Bell, P. A. (1978). Affective state, attraction, and affiliation: Misery loves happy company, too. Personality and Social Psychology Bulletin, 4, 616-619.

Berkowitz, L. (1987). Mood, self-awareness, and willingness to help. Journal of Personality and Social Psychology, 52, 721-729.

Bless, H., Bohner, G., Schwarz, N., \& Strack, F. (1990). Mood and persuasion: A cognitive response analysis. Personality and Social Psychology Bulletin, 16, 331-345.

Bodenhausen, G. V., Kramer, G. P., \& Süsser, K. (1994). Happiness and stereotypic thinking in social judgment. Journal of Personality and Social Psychology, 66, 621-632.

Borman, W. C., Penner, L. A., Allen, T. D., \& Motowidlo, S. J. (2001). Personality predictors of citizenship performance. International Journal of Selection and Assessment, 9, 52-69.

Brown, J. (1984). Effects of induced mood on casual attributions for success and failure. Motivation and Emotion, 8, 343-353.

Burger, J. M., \& Caldwell, D. F. (2000). Personality, social activities, job-search behavior and interview success: Distinguishing between PANAS trait positive affect and NEO extraversion. Motivation and Emotion, 24, 51-62.

Cantor, N., Norem, J., Langston, C., Zirkel, S., Fleeson, W., \& Cook-Flannagan, C. (1991). Life tasks and daily life experience. Journal of Personality, 59, 425-451.

Carnevale, P. J. D., \& Isen, A. M. (1986). The influence of positive affect and visual access on the discovery of integrative solutions in bilateral negotiation. Organizational Behavior and Human Decision Processes, 37, 1-13.

Carver, C. S. (2003). Pleasure as a sign you can attend to something else: Placing positive feelings within a general model of affect. Cognition and Emotion, 17, 241-261.

Carver, C. S., \& Scheier, M. F. (1998). On the self-regulation of behavior. New York: Cambridge University Press.

Connolly, J. J., \& Viswesvaran, C. (2000). The role of affectivity in job satisfaction: A meta-analysis. Personality and Individual Differences, 29, 265-281.

Coté, S. (1999). Affect and performance in organizational settings. Current Directions in Psychological Science, 8, 65-68.

Credé, M., Chernyshenko, O. S., Stark, S., Dalal, R. S., \& Bashshur, M. (2005). The relationship of job satisfaction to personological and environmental antecedents and volitional workplace behavior. Manuscript submitted for publication.

Cropanzano, R., \& Wright, T. A. (1999). A 5 -year study of change in the relationship between wellbeing and job performance. Consulting Psychology Journal: Practice and Research, 51, 252-265.

Cunningham, M. R., Steinberg, J., \& Grev, R. (1980). Wanting to and having to help: Separate motivations for positive mood and guilt-induced helping. Journal of Personality and Social Psychology, 38, 181-192.

DeLuga, R. J., \& Mason, S. (2000). Relationship of resident assistant conscientiousness, extraversion, and positive affect with rated performance. Journal of Research in Personality, 34, 225-235.

Diener, E., \& Biswas-Diener, R. (2002). Will money increase subjective well-being? A literature review and guide to needed research. Social Indicators Research, 57, 119-169. 
Diener, E., Nickerson, C., Lucas, R. E., \& Sandvik, E. (2002). Dispositional affect and job outcomes. Social Indicators Research, 59, 229-259.

Diener, E., Sandvik, E., \& Pavot, W. (1991). Happiness is the frequency, not the intensity, of positive versus negative affect. In F. Strack, M. Argyle, \& N. Schwartz (Eds.), Subjective well-being: An interdisciplinary perspective (pp. 119-139). Oxford, UK: Pergamon.

Edwards, J. A., \& Weary, G. (1993). Depression and the impression-formation continuum: Piecemeal processing despite the availability of category information. Journal of Personality and Social Psychology, 64, 636-645.

Elliot, A. J., \& Thrash, T. M. (2002). Approach-avoidance motivation in personality: Approach and avoidance temperaments and goals. Journal of Personality and Social Psychology, 82, 804-818.

Elsbach, K. D., \& Barr, P. S. (1999). The effects of mood on individuals' use of structured decision protocols. Organization Science, 10, 181-198.

Estrada, C., Isen, A. M., \& Young, M. J. (1994). Positive affect influences creative problem solving and reported source of practice satisfaction in physicians. Organizational Behavior and Human Decision Processes, 72, 117-135.

Feingold, A. (1983). Happiness, unselfishness, and popularity. The Journal of Psychology, 115, 3-5.

Fisher, C. D. (2002). Antecedents and consequences of real-time affective reactions at work. Motivation and Emotion, 26, 3-30.

Forgas, J. P. (1998). On feeling goof and getting your way: Mood effects on negotiator cognition and bargaining strategies. Journal of Personality and Social Psychology, 74, 565-577.

Fredrickson, B. L. (1998). What good are positive emotions? Review of General Psychology, 2, 300-319.

Fredrickson, B. L. (2001). The role of positive emotions in positive psychology: The broaden-andbuild theory of positive emotions. American Psychologist, 56, 218-226.

Fredrickson, B. L., \& Branigan, C. (2005). Positive emotions broaden the scope of attention and thought-action repertoires. Cognition and Emotion, 19, 313-332.

George, J. M. (1989). Mood and absence. Journal of Applied Psychology, 74, 317-324.

George, J. M. (1991). State or trait: Effects of positive mood on prosocial behaviors at work. Journal of Applied Psychology, 76, 299-307.

George, J. M. (1995). Leader positive mood and group performance: The case of customer service. Journal of Applied Psychology, 25, 778-795.

George, J. M., \& Brief, A. P. (1992). Feeling good-doing good: A conceptual analysis of the mood at work-organizational spontaneity relationship. Psychological Bulletin, 112, 310-329.

Gil, K. M., Carson, J. W., Porter, L. S., Scipio, C., Bediako, S. M., \& Orringer, E. (2004). Daily mood and stress predict pain, health care use, and work activity in African American adults with Sickle-cell disease. Health Psychology, 23, 267-274.

Graham, C., Eggers, A., \& Sukhtankar, S. (2004). Does happiness pay? An exploration based on panel data from Russia. Journal of Economic Behavior E Organization, 55, 319-342.

Grawitch, M. J., Munz, D. C., Elliott, E. K., \& Mathis, A. (2003). Promoting creativity in temporary problem-solving groups: The effects of positive mood and autonomy in problem definition on idea-generating performance. Group Dynamics: Theory, Research, and Practice, 7, 200-213.

Grawitch, M. J., Munz, D. C., \& Kramer, T. J. (2003). Effects of member mood states on creative performance in temporary workgroups. Group Dynamics: Theory, Research, and Practice, 7, 41-54.

Griffitt, W. B. (1970). Environmental effects of interpersonal affective behavior: Ambient effective temperature and attraction. Journal of Personality and Social Psychology, 15, 240-244.

Harker, L., \& Keltner, D. (2001). Expressions of positive emotion in women's college yearbook pictures and their relationship to personality and life outcomes across adulthood. Journal of Personality and Social Psychology, 80, 112-124.

Herrbach, O. (2006). A matter of feeling? The affective tone of organizational commitment and identification. Journal of Organizational Behavior, 27, 629-643.

Hom, H., \& Arbuckle, B. (1988). Mood induction effects upon goal setting and performance in young children. Motivation and Emotion, 12, 113-122.

Iaffaldano, M. T., \& Muchinsky, P. M. (1985). Job satisfaction and job performance: A meta-analysis. Psychological Bulletin, 97, 251-273. 
Ilies, R., Scott, B. A., \& Judge, T. A. (2006). The interactive effects of personal traits and experienced states on intraindividual patterns of citizenship behavior. Academy of Management Journal, 49, 561-575.

Isen, A. M. (1970). Success, failure, attention and reaction to others: The warm glow of success. Journal of Personality and Social Psychology, 15, 294-301.

Isen, A. M. (1993). Positive affect and decision making. In M. Lewis \& J. M. Haviland-Jones (Eds.), Handbook of emotions (2md ed., pp. 417-435). New York: Guilford.

Isen, A. M., Daubman, K. A., \& Nowicki, G. P. (1987). Positive affect facilitates creative problem solving. Journal of Personality and Social Psychology, 52, 1122-1131.

Isen, A. M., Johnson, M. M., Mertz, E., \& Robinson, G. F. (1985). The influence of positive affect on the unusualness of word associations. Joumal of Personality and Social Psychology, 48, 1413-1426.

Isen, A. M., \& Levin, P. F. (1972). Effect of feeling good on helping: Cookies and kindness. Journal of Personality and Social Psychology, 21, 384-388.

Isen, A. M., \& Means, B. (1983). The influence of positive affect on decision-making strategy. Social Cognition, 2, 18-31.

Iverson, R. D., Olekalns, M., \& Erwin, P. J. (1998). Affectivity, organizational stressors, and absenteeism: A causal model of burnout and its consequences. Journal of Vocational Behavior, 52, 1-23.

Judge, T. A., \& Ilies, R. (2004). Affect and job satisfaction: A study of their relationship at work and at home. Journal of Applied Psychology, 4, 661-673.

Judge, T. A., Thoresen, C. J., Bono, J. E., \& Patton, G. K. (2001). The job satisfaction-job performance relationship: A qualitative and quantitative review. Psychological Bulletin, 127, 376-407.

Judge, T. A., Thoresen, C. J., Pucik, V., \& Welbourne, T. M. (1999). Managerial coping with organizational change: A dispositional perspective. Journal of Applied Psychology, 84, 107-122.

Kashdan, T. B., Rose, P., \& Fincham, F. D. (2004). Curiosity and exploration: Facilitating positive subjective experiences and personal growth opportunities. Journal of Personality Assessment, 82, 291-305.

Lee, K., \& Allen, N. J. (2002). Organizational citizenship behavior and workplace deviance: The role of affect and cognitions. Journal of Applied Psychology, 87, 131-142.

Lucas, R. E., Clark, A. E., Georgellis, Y., \& Diener, E. (2004). Unemployment alters the set point for life satisfaction. Psychological Science, 15, 8-13.

Lucas, R. E., \& Diener, E. (2003). The happy worker: Hypotheses about the role of positive affect in worker productivity. In M. Burrick \& A. M. Ryan (Eds.), Personality and work (pp. 30-59). San Francisco: Jossey-Bass.

Lyubomirsky, S., King, L., \& Diener, E. (2005). The benefits of frequent positive affect: Does happiness lead to success? Psychological Bulletin, 131, 803-855.

Mackie, D. M., \& Worth, L. T. (1989). Processing deficits and the mediation of positive affect in persuasion. Journal of Personality and Social Psychology, 57, 27-40.

Madjar, N., Oldham, G. R., \& Pratt, M. G. (2002). There's no place like home? The contributions of work and nonwork creativity support to employees' creative performance. Academy of Management Journal, 45, 747-767.

Marks, G. N., \& Fleming, N. (1999). Influences and consequences of well-being among Australian young people: 1980-1995. Social Indicators Research, 46, 301-323.

Melton, R. J. (1995). The role of positive affect in syllogism performance. Personality and Social Psychology Bulletin, 21, 788-794.

Mignonac, K., \& Herrbach, O. (2004). Linking work events, affective states, and attitudes: An empirical study of managers' emotions. Journal of Business and Psychology, 19, 221-240.

Miles, D. E., Borman, W. E., Spector, P. E., \& Fox, S. (2002). Building an integrative model of extra role work behaviors: A comparison of counterproductive work behavior with organizational citizenship behavior. International Journal of Selection and Assessment, 10, 51-57.

Oishi, S., Diener, E., \& Lucas, R. E. (2006). Optimum level of well-being: Can people be too happy? Manuscript submitted for publication.

O'Malley. M. N., \& Andrews, L. (1983). The effect of mood on incentives on helping: Are there some things money can't buy? Motivation and Emotion, 7, 179-189. 
Pelled, L. H., \& Xin, K. R. (1999). Down and out: An investigation of the relationship between mood and employee withdrawal behavior. Journal of Management, 6, 875-895.

Pinquart, M., \& Sorensen, S. (2000). Influences of socioeconomic status, social network, and competence on subjective well-being in later life: A meta-analysis. Psychology and Aging, 15, 187-224.

Roberts, B. W., Caspi, A., \& Moffitt, T. E. (2003). Work experiences and personality development in young adulthood. Journal of Personality and Social Psychology, 84, 582-593.

Rosenhan, D. L., Salovey, P., \& Hargis, K. (1981). The joys of helping: Focus of attention mediates the impact of positive affect on altruism. Joumal of Personality and Social Psychology, 40, 899-905.

Rosenhan, D. L., Underwood, B., \& Moore, B. (1974). Affect moderates self-gratification and altruism. Journal of Personality and Social Psychology, 30, 546-552.

Sarason, I. G., Potter, E. H., \& Sarason, B. R. (1986). Recording and recall of personal events: Effects on cognitions and behavior. Journal of Personality and Social Psychology, 2, 347-356.

Seligman, M. E. P., \& Schulman, P. (1986). Explanatory style as a predictor of productivity and quitting among life insurance sales agents. Journal of Personality and Social Psychology, 50, $832-838$.

Staw, B. M., \& Barsade, S. G. (1993). Affect and managerial performance: A test of the sadder-butwiser vs. happier-and-smarter hypotheses. Administrative Science Quarterly, 38, 304-331.

Staw, B. M., Sutton, R. I., \& Pelled, L. H. (1994). Employee positive emotion and favorable outcomes at the workplace. Organization Science, 5, 51-71.

Taylor, S. E., Lerner, J. S., Sherman, D. K., Sage, R. M., \& McDowell, N. K. (2003). Portrait of the self-enhancer: Well adjusted and well liked or maladjusted and friendless? Journal of Personality and Social Psychology, 84, 165-176.

Thoits, P. A., \& Hewitt, L. N. (2001). Volunteer work and well-being. Journal of Health and Social Behavior, 42, 115-131.

Thoresen, C. J., Kaplan, S. A., Barsky, A. P., Warren, C. R., \& de Chermont, K. (2003). The affective underpinnings or job perceptions and attitudes: A meta-analytic review and integration. Psychological Bulletin, 129, 914-945.

Totterdell, P. (1999). Mood scores: Mood and performance in professional cricketers. British Journal of Psychology, 90, 317-332.

Totterdell, P. (2000). Catching moods and hitting runs: Mood linkage and subjective performance in professional sport teams. Journal of Applied Psychology, 85, 848-859.

Van Katwyk, P. T., Fox, S., Spector, P. E., \& Kelloway, E. K. (2000). Using the Job-Related Affective Well-being Scale (JAWS) to investigate affective responses to work stressors. Journal of Occupational Health Psychology, 52, 219-230.

Watson, D., \& Slack, A. K. (1993). General factors of affective temperament and their relation to job satisfaction over time. Organizational Behavior and Human Decision Processes, 54, 181-202.

Watson, D., Wiese, D., Vaidya, J., \& Tellegen, A. (1999). The two general activation systems of affect: Structural findings, evolutionary considerations, and psychobiological evidence. Journal of Personality and Social Psychology, 76, 820-838.

Weiss, H. M., Nicholas, J. P., \& Daus, C. S. (1999). An examination of the joint effects of affective experiences and job beliefs on job satisfaction and variations in affective experiences over time. Organizational Behavior and Human Decision Processes, 78, 1-24.

Williams, S., \& Shiaw, W. T. (1999). Mood and organizational citizenship behavior: The effects of positive affect on employee organizational citizenship behavior intentions. The Journal of Psychology, 133, 656-668.

Wright, T. A., \& Cropanzano, R. (1998). Emotional exhaustion as a predictor of job performance and voluntary turnover. Journal of Applied Psychology, 83, 486-493.

Wright, T. A., \& Cropanzano, R. (2000). Psychological well-being and job satisfaction as predictors of job performance. Journal of Occupational Health Psychology, 5, 84-94.

Wright, J., \& Mischel, W. (1982). Influence of affect on cognitive social learning person variables. Journal of Personality and Social Psychology, 43, 901-914.

Wright, T. A., \& Staw, B. M. (1999). Affect and favorable work outcomes: Two longitudinal tests of the happy-productive worker thesis. Journal of Organizational Behavior, 20, 1-23. 